\title{
DYNAMIC CAPABILITIES AND PERFORMANCE OF HOSPITALITY FIRMS IN SOUTH AFRICA: THE MEDIATING EFFECT OF INNOVATION
}

\author{
Olawale FATOKI* \\ University of Limpopo, Department of Business Management, Mankweng, South Africa, e-mail: olawale.fatoki@ul.ac.za
}

\begin{abstract}
Citation: Fatoki, O. (2021). DYNAMIC CAPABILITIES AND PERFORMANCE OF HOSPITALITY FIRMS IN SOUTH AFRICA: THE MEDIATING EFFECT OF INNOVATION. GeoJournal of Tourism and Geosites, 36(2spl), 616-623. https://doi.org/10.30892/gtg.362spl08-690
\end{abstract}

\begin{abstract}
Dynamic capabilities describe a firm's ability to build, integrate and reconfigure internal and external competencies to address rapidly changing environments and improve firm competitiveness. The aim of the study was to investigate the effect of four dimensions of dynamic capabilities (sensing, learning, integrating, and coordinating) on the performance of hospitality firms. In addition, the study examined the mediating role of product innovation in the relationship between dynamic capabilities and performance. The study adopted the quantitative research design and the cross-sectional survey method was used for data collection. The Partial Least Square Structural Equation Modelling was used for data analysis. Based on a dataset of 135 respondents, the results indicated that sensing, learning and coordinating significantly affect the performance of hospitality firms. Innovation mediates the relationship between sensing and learning capabilities and performance. Theoretical and managerial implications are discussed. The provision of seminars and training on dynamic capabilities and innovation to top management and employees is important.
\end{abstract}

Key words: Dynamic capabilities, hospitality, firm, performance, innovation

\section{INTRODUCTION}

The socio-economic development of many countries and regions around the world is dependent on tourism. Tourism is one of the strategies adopted by local authorities in South Africa to stimulate socio-economic development (Ntshangase and Ezeuduji, 2020; Gorochnaya et al., 2021). The tourism industry including the hospitality sector is one of the most important pillars of the South African economy. Tourism directly contributed $2.8 \%$ and indirectly accounted for $8.2 \%$ of South Africa's gross domestic product in 2018. In addition, the tourism industry directly accounted for $4.2 \%$ and indirectly contributed $9.2 \%$ of total employment in 2018 (World Travel and Tourism Council, 2019). Skokic et al. (2016) and Richard (2017) point out that the future of the hospitality sector especially hotels will be shaped by technological advancement, changing customer expectations, fierce competition in the market and uncertainties in the business environment. Hospitality firms in South Africa operate in a dynamic environment that is characterised by high levels of competition and innovative capabilities are one of the major sources of competitive advantage and survival (Chipunza, 2020; Senbeto and Hon, 2020). The South African economy is characterised by a low level economic growth and a high level of unemployment and these factors have negatively affected consumer confidence and the consumption of goods and services (Pasara and Garidzirai, 2020).

The building of capabilities becomes vital under these circumstances. Firms need to renew their resources in order to adjust to changing environmental conditions (Nieves et al., 2016). Dynamic capabilities (DC) describe a firm's ability to build, integrate and reconfigure internal and external competencies to address rapidly changing environments and improve firm competitiveness. DC enable a firm to sense and seize new opportunities and renew its existing market base and can be used to explain the association between the quality of management decisions, strategic change and firm performance (Teece et al., 2007; Barreto, 2010; Zhou et al., 2017). Pavlou and El Sawy (2011) point out that DC has four dimensions namely sensing, learning, integrating and coordinating. The effect of DC on firm competitive advantage and performance has been a major issue of debate by researchers (Peteraf et al., 2014; Zhou et al., 2017). Barreto (2010) contends that early studies assumed a direct relationship between DC and firm performance and used the construct to explain firm level competitive advantage, success and failure.

Teece et al. (1997) and Teece (2017) propose that DC have a positive effect on firm performance and the construct can be used to understand the fundamentals of firm-level competitive advantage. Makadok (2001) argues that DC are a causal mechanism that can be used by firms to create economic profit. Zollo and Winter (2002) contend that in changing environmental conditions, there is a direct and positive relationship between DC and superior performance and survival of firms. Nedzinskas et al. (2013) find that the direct effect of DC on financial performance is insignificant but the direct effect on non-financial performance is positive and significant. In contrast, another stream of research assumes an indirect relationship between DC and firm performance. Eisenhardt and Martin (2000) and Zott (2003) argue that DC do not automatically improve firm performance. Competitive advantage and improved firm performance do not necessarily rely on DC but on resource configurations that they create. Zahra et al. (2006) contend that the relationship between DC and performance is indirect and is obtained by the way that DC change the quality of substantive capabilities. In addition, DC can actually damage firm performance if used when not needed. Winter (2003) finds that the cost and long-term commitment of resources may make DC unnecessary and costly for a firm to develop and use. Zhou et al.

\footnotetext{
Corresponding author
} 
(2017) note that the debate about the effect of DC on performance arose because the mechanisms through which DC affect firm performance is unclear. In addition, DC studies have been mainly theoretical and empirical studies have been lagging. Studies on mediating mechanisms have been scarce. Because DC can have a direct or an indirect effect on firm performance, it is important to identify the variables that can have mediating effects in the relationship between the two constructs. One variable whose mediating effect can be examined is innovation. This is because innovation is vital to a firm's competitive advantage and superior performance (He and Wong, 2004; Jensen et al., 2007; Ferreira et al., 2020). Kogabayev and Maziliauskas (2017) describe firm level innovation as the generation of new ideas and the creation of new products, processes and services that lead to increase in performance. Innovation can help a firm to adapt and shape the business environment and are vital to patronage and loyalty in the hospitality industry. The types of innovation used in the hospitality industry include product/service, process, organisational and marketing. This study focuses on product/service innovation. Product and servicecentric innovations are vital for maintaining and attracting customers and the sustainability of hospitality firms (Martin-Rios and Ciobanu, 2018; Onojaefe and Nhepera, 2019). However, theoretical frameworks and empirical studies on how innovation mediates the relationship between DC and firm performance are scarce (Zhou et al., 2017).

Therefore, this study has two objectives: First, the study will examine the effect of DC on the performance of hospitality firms. Second, the study will investigate the mediating effect of innovation in the relationship between DC and performance. The study will contribute to knowledge in the following ways. First, although DC is an important framework for understanding firm competitive advantage, empirical research focusing on the hospitality industry is scarce (Nieves et al., 2017)) and studies focusing on mediating mechanisms are more scarce (Zhou et al., 2017). Second, recent studies have tended to adopt the multidimensional measure of DC (Teece, 2007; Nieves et al., 2017). However, empirical findings on the effects of the various dimensions of DC on performance are inconclusive. This study will contribute to the literature on the use of strategic management by hospitality firms and particularly on the direct or indirect relationship between DC and performance. This can assist hospitality firms to design strategic management policies that can help to improve their competitive advantage and performance. The study is structured as follows. Section two will review the literature and develop hypotheses. Sections three, four, five and six will focus on the research methodology, results, discussion and conclusion respectively.

\section{LITERATURE REVIEW AND DEVELOPMENT OF HYPOTHESES}

\section{Theoretical foundation of DC}

The theoretical foundation of DC can be linked to the Resource-Based View (RBV). According to Teece et al., 1997), the foundation of RBV goes back to the 1960s and can be associated with the work of Penrose (1959) and Andrews (1971). However, Barney (1991) clarified the link between resources and sustainable competitive advantage. The RBV focuses on how a firm uses resources and capabilities to reach a position of sustained competitive advantage and a higher level of performance. According to the RBV, a firm is a collection of distinctive resources and capabilities that must be optimally employed by management. The RBV argues that firms are heterogeneous in terms of capabilities, competencies and resources and their long-term success depends on how they efficiently and effectively utilise these capabilities in the dynamic marketplace. In addition, for a resource to contribute to sustainable competitive advantage, it must be rare, valuable, inimitable, and nonsubstitutable. According to Amit and Schoemaker (1993), it is not just resources but also capabilities described as the ability of a firm to deploy resources and bundles of skills and knowledge that are the real causes of competitive advantages. In addition, capabilities can be operational or dynamic. Operational capabilities can be described as routines that allow a firm to accomplish tasks on an on-going basis by using the same techniques over time in the production of goods and services with solid demand in the market. Dynamic capabilities (DC) describe a firm's ability to make adjustments as it operates in a changing business environment (Helfat and Winter, 2011; Božič and Cvelbar, 2016; Seo et al., 2021).

\section{Dynamic capabilities (DC)}

Barreto (2010) points out that although researchers have provided a huge array of different conceptualisations of DC, Teece et al. (1997) offer what can be regarded as the most important study on this topic and the first widely acknowledged definition. Teece et al. (1997) propose that the DC approach as an extension of the RBV of the firm. Teece et al. (1997: 516) define DC as "the firm's ability to integrate, build, and reconfigure internal and external competences to address rapidly changing environments". Helfat et al. (2007: 4) define DC as "the capacity of an organisation to purposefully create, extend, or modify its resource base'. Similar to Teece et al. (1997), Eisenhardt and Martin (2000:1107) define DC as "the firm's processes that use resources - specifically the processes to integrate, reconfigure, gain, and release resources - to match and even create market change". Drawing on previous definitions, Bareto (2010: 271) defines DC as "the firm's potential to systematically solve problems, formed by its propensity to sense opportunities and threats, to make timely and market-oriented decisions, and to change its resource base". DC have been classified into various dimensions by researchers. Teece et al. (1997) classify DC into three main dimensions, which are sensing, seizing and transforming. Teece's classification of DC is one of the most widely used approaches by researchers (Zhou et al., 2017). Pavlou and El Sawy (2011) argue that the framework of DC by Teece et al. (1997) has been produced at an abstract level and has failed to offer an appropriate measurement procedure. Based on these limitations, Pavlou and El Sawy (2011) propose an operationalisation of DC through four processes: sensing, learning, integrating and coordinating. This conceptualisation has been used by recent researchers on DC (Nieves et al., 2017; Rashidirad and Salimian 2020) and will be adopted by this study.

\subsection{DC and performance}

\subsubsection{Sensing capability and performance}

In a dynamic business environment, customer needs, competitor action and technology are regularly in a situation of flux. Sensing involves the scanning, creation and interpretive activities of new opportunities. Sensing entails investment in research 
activity, probing of technological possibilities and customer needs, understanding latent demand, the evolution of industries and markets and the responses of competitors and suppliers (Teece, 2007; Nieves et al., 2017). Rashidirad and Salimian (2020) point out that sensing capability focuses on the search for opportunities and threats in order to shape and interpret opportunities in the market. Sensing capability has both an internal (firm-level) and an external aspect as it helps to create both interorganisation and external information to monitor changes in the environment. In addition, sensing capability regularly explores and analyses information and knowledge to provide management with information to make effective decisions. Rashidirad and Salimian (2020) find that sensing capability is positively related to value creation defined as the non-financial aspects of performance measurement from the viewpoint of the stakeholders.

\subsubsection{Learning capability and performance}

Duchek (2020) remarks that because of growing complexity and uncertainty in the world, it is important to encourage the capability of individuals and firms to learn regularly in order to continuously adapt to changing environments. The ability to learn faster than competitors is one of the ways for a firm to create sustainable competitive advantage. Matysiak et al. (2018) describe learning capability as the ability of a firm to use the opportunities identified through sensing capability to develop and introduce new products and services. Learning can be internal or external. Internal learning can be acquired through the training of employees by a firm while external learning can be gained through interaction with customers and suppliers. Learning helps firms to create value in a dynamic business environment and is an asset that enables a firm to transform and use its resources appropriately (Zott, 2003; Nieves et al., 2017; Rashidirad and Salimian, 2020).

\subsubsection{Integrating capability and performance}

Teece et al. (1997) and Teece (2007) point out that integrating capability focuses on the transfer of information or technology amongst various units of a firm. Integration enables learning, sharing of knowledge and expertise and technology transfer within a firm. Integration capability enables a firm to appraise the value of existing resources and integrate them. This enables the firm to cultivate a new resource base and capabilities, which improves the ability of the firm to meet environmental challenges (Oliva et al., 2019). Integrating capability includes integrating the resource base in the firm as a whole, integrating existing and new knowledge obtained from external partners and integrating customer knowledge obtained from different units of a firm in order to gain new customers. Integrating capability helps a firm to combine the knowledge of different individuals and units into new operational capabilities (Nieves and Haller, 2014; Rashidirad and Salimian, 2020).

\subsubsection{Coordinating capability and performance}

Rehman and Saeed (2015) remark that coordination capability enables a firm to integrate all the tacit knowledge as well as codified knowledge in order to produce and deliver products and obtain data about the needs and demands of the customers. Coordinating capability helps to manage dependencies between firm activities and administers resources, task and activities in order to deploy the reconfigured operational capabilities (Aminu and Mahmood, 2015; Rengkung, 2018). Coordinating capability helps to assign resources to a task, appoint a right person to a right job, identify complementarities and synergies among tasks and resources and orchestrate collective activities. This enables a firm to manage a rapidly changing business environment, sustain competitiveness, maintain customers and improve performance through a dynamic redirecting and realigning the resource base (Pavlou and El-Sawy, 2011).

It is hypothesised that:

H 1-4: DC as measured by (a) sensing (b) learning, (3) integrating (d) coordination are positively related to performance.

\section{DC, innovation and performance}

Innovation can be described as a new idea, product, device or novelty. It is a multi-stage process that a firm uses to transform ideas into new products, services or processes to compete and differentiate itself in the market place (Baregheh et al. (2009). Product innovation also involves the introduction of new products and services through technological novelty with the aim of providing a hospitality firm with a competitive advantage by decreasing costs and opening the pathway to new markets. The introduction of new products by the hospitality firms can be internally or externally generated based on the degree of complexity with new technologically-oriented products being for the most part externally generated (Martin-Rios and Ciobanu, 2018). Jiang et al. (2019) point out that a firm can use product innovation to redefine its current product markets and develop new products to capture new market opportunities. Thus, product innovation is a key driver of sustainable competitive advantage and survival and especially in situations characterised by intense market competition, changing market preferences and technological discontinuities. Mabrouk and Mamoghli (2010) find that product innovation in the hospitality industry is a major driver of customer satisfaction, customer retention and profitability. The implementation of innovation enables a firm to become more flexible in its operations and drives the firm to improve the quality of its products, expansions of network and technology competitiveness According to Likoum et al. (2018), sensing describes the ability of a firm to respond to customer tastes and demand, changes in technological advancement and the market environment. Innovation occurs because of a firm's ability to sense the market and anticipate changes in the business environment (Alshanty and Emeagwali, 2019) find that market-sensing capability has a positive effect on knowledge creation and firm innovation and the knowledge creation process positively affects firm innovation. According to Migdadi (2019), learning enables a firm to appreciate and assimilate new ideas and is an antecedent of innovation. Learning involves acquisition, transmission and use of knowledge and is closely linked to innovation performance. Jiménez-Jiménez and Sanz-Valle (2011) examine the association between learning, innovation and performance and found significant positive relationships. Learning capability is a significant factor in firm innovation and 
growth. Mesa et al. (2013) find that learning capability improves product innovation through the mediation of design management capability. Learning capability is an asset that enables a firm to transform and use its resources properly and a high level of innovation requires a high and effective level of learning capability. Integration capability can positively affect innovation by helping the firm to integrate new technology with existing one in order to create new products and improve firm process. Effective integration of internal and external knowledge leads to the development of new products that can positively affect firm performance (Zhou et al. 2017). Innovation activities of different individuals and units in an organisation need cohesiveness and coordinating capability in order to be effective and improve firm performance Rajapathirana and Hui, 2018).

It is hypothesised that:

H5-H8: DC as measured by (a) sensing (b) learning, (3) integrating (d) coordination are positively related to product innovation

H9: Product innovation is positively related to performance

H10-H13: Product innovation mediates the relationship between DC (sensing, learning, integrating and coordinating) and performance

\section{RESEARCH METHODOLOGY}

The study utilised the quantitative research design. Data was collected from the respondents through the cross-sectional survey method. The sample population was all hotels, lodges and guesthouses in South Africa. Before the actual survey, a pilot study was conducted with the owner/manager of twenty hotels, guesthouses and lodges in Polokwane. Two academics in the area of Strategic Management also examined the questionnaire. Based on the results of the pilot study, minor adjustments were made to the final version of the questionnaire. The survey was conducted between September 2019 and February 2020. The questionnaire was divided into four sections demographic variables, dimensions of DC, innovation and performance. The study focused on small and medium-sized guesthouses, lodges and hotels in Pretoria and Johannesburg in the Gauteng Province and Polokwane, Makopane and Bela Bela in the Limpopo Province. The Gauteng Province is the economic hub of South Africa and many hotels, guesthouses and lodges are located in the Province. The three towns in Limpopo province have a sizeable number of hotels. The participating guesthouses, lodges and hotels were developed by the researcher from the websites of the Tourism Grading Council of South Africa and Trivago. The Tourism Grading Council of South Africa is an independent assessment agency that has established standards by which guests can compare facilities in different guesthouses, lodges and hotels in South Africa. Trivago is a transnational technology company that specialises in internet-related products and services in the lodging, hotel and metasearch fields. The number of employees was used to classify the hotels. According to the National Small Business Act of South Africa (2019), a micro enterprise in the accommodation industry will have between 0-10 employees, a small enterprise between 11-50 employees and a medium-sized 51-250 employees. Accommodation firms that have more than 250 employees are considered as large.

Table 1. Questionnaire (author's adaptation)

\begin{tabular}{|c|c|c|c|}
\hline Construct & Items & $\begin{array}{l}\text { Adapted } \\
\text { from }\end{array}$ & $\begin{array}{l}\text { Response } \\
\text { category }\end{array}$ \\
\hline \multicolumn{4}{|l|}{$\begin{array}{c}\text { Dynamic } \\
\text { capabilities }\end{array}$} \\
\hline $\begin{array}{l}\text { Sensing } \\
\text { capability }\end{array}$ & $\begin{array}{l}\text { 1. Frequently scan the en Table ironment to identify new business opportunities. } \\
\text { 2. Periodically review the likely effect of changes in our business environment on customers. } \\
\text { 3. Regularly review our service development efforts to ensure they are in line with what customers want. } \\
\text { 4. Spend a great deal of time implementing ideas for new services and improving our existing services. }\end{array}$ & $\begin{array}{l}\text { Pavlou and } \\
\text { ElSawy, } \\
\text { 2011; Nieves } \\
\text { et al., } 2016 \\
\end{array}$ & $\begin{array}{l}1=\text { strongly } \\
\text { disagree, } \\
5 \text { strongly } \\
\text { agree }\end{array}$ \\
\hline $\begin{array}{l}\text { Learning } \\
\text { capability }\end{array}$ & $\begin{array}{l}\text { 1. Have effective routines to identify, value and import new information and knowledge. } \\
\text { 2. Have appropriate routines to assimilate new information and knowledge. } \\
\text { 3. Effective in transforming existing information into new knowledge. } \\
\text { 4. Effective in utilizing knowledge in new services. } \\
\text { 5. Effective in developing new knowledge that has the potential to influence service development. }\end{array}$ & $\begin{array}{l}\text { Pavlou and } \\
\text { ElSawy, } \\
2011 ; \\
\text { Nieves } \\
\text { et al., } 2016 \\
\end{array}$ & $\begin{array}{l}1=\text { strongly } \\
\text { disagree, } \\
5 \text { strongly } \\
\text { agree }\end{array}$ \\
\hline $\begin{array}{l}\text { Integrating } \\
\text { capability }\end{array}$ & $\begin{array}{l}\text { 1. Employee's individual contributions are channelled through their work group. } \\
\text { 2. Members of the firm have a global understanding of each other's tasks and responsibilities. } \\
\text { 3. Fully aware of who in the firm has specialized skills and knowledge relevant to our work. } \\
\text { 4. Carefully interrelate actions between members of the firm to meet changing conditions. } \\
\text { 5. Members of the firm manage to successfully interconnect their activities. }\end{array}$ & $\begin{array}{l}\text { Pavlou and } \\
\text { ElSawy, } \\
2011 ; \\
\text { Nieves } \\
\text { et al., } 2016 \\
\end{array}$ & $\begin{array}{l}1=\text { strongly } \\
\text { disagree, } \\
5 \text { strongly } \\
\text { agree }\end{array}$ \\
\hline $\begin{array}{c}\text { Coordinating } \\
\text { capability }\end{array}$ & $\begin{array}{l}\text { 1. Ensure that the output of each employee's work is synchronized with that of the rest of the group. } \\
\text { 2. Ensure appropriate allocation of resources (e.g. information, time, reports. } \\
\text { 3. Employees are assigned to tasks commensurate with their relevant knowledge and skills. } \\
\text { 4. Ensure that employees' expertise is compatible with the work processes they are assigned to. } \\
\text { 5. Our employees are well coordinated. }\end{array}$ & $\begin{array}{l}\text { Pavlou and } \\
\text { ElSawy, } \\
2011 ; \\
\text { Nieves } \\
\text { et al., } 2016 \\
\end{array}$ & $\begin{array}{l}1=\text { strongly } \\
\text { disagree, } \\
5 \text { strongly } \\
\text { agree }\end{array}$ \\
\hline $\begin{array}{l}\text { Product } \\
\text { innovation }\end{array}$ & $\begin{array}{l}\text { 1. Introduced many new services onto the market. } \\
\text { 2. Introduced many modifications to existing services. } \\
\text { 3. Constantly seeks out new services. } \\
\text { 4. Introduced more new services than our competitors. } \\
\text { 5. New services introduced have caused significant changes in the industry. }\end{array}$ & $\begin{array}{l}\text { Nieves } \\
\text { et al., } 2016\end{array}$ & $\begin{array}{l}1=\text { strongly } \\
\text { disagree, } \\
5 \text { strongly } \\
\text { agree }\end{array}$ \\
\hline Performance & $\begin{array}{l}\text { 1. Profit growth } \\
\text { 2. Sales growth } \\
\text { 3. Market share } \\
\text { 4. Quality of products relative to competitors } \\
\text { 5. Customer retention relative to competitors } \\
\text { 6. Customer satisfaction relative to competitors } \\
\text { 7. Customer retention relative to competitors }\end{array}$ & $\begin{array}{l}\text { Spillan } \\
\text { and Parnell } \\
2006\end{array}$ & $\begin{array}{l}\text { T1=strongly } \\
\text { disagree, } \\
5 \text { strongly } \\
\text { agree }\end{array}$ \\
\hline
\end{tabular}


Micro lodges, guesthouses and hotels were excluded from the survey. Nieves et al. (2017) remark that higher category hotels are more formalised and professionalised are more likely to be involved in DC and innovative activities. The simple sampling method was used to select the participating establishments in the study areas. Managers/owners of accommodation establishments were formally contacted through telephone calls and e-mails to solicit their participation. A combination of email and self-administered questionnaire methods was used to collect data from the respondents. Confidentiality and anonymity were assured and the names of the hotels and or owner/manager were not requested and not included in the questionnaire. The participants in the survey were reminded weekly to complete the questionnaire through follow up phone calls and emails. If no response is received after two months, it was treated as a nonresponse. The questionnaire was adapted from previous studies with acceptable psychometric properties. The cover page of the questionnaire contained information about the objectives of the study and that participation is voluntary. The study used the Partial Least Square Structural Equation Modelling (PLS SEM) for data analysis. Table 1 depicts the questionnaire used by the study.

\section{RESULTS}

\section{Response rate and biographical detail}

Three hundred questionnaires were distributed and one hundred and thirty-five returned. The majority of the accommodation firms that participated in the survey have operated for more than ten years (82\%) and can be regarded as small establishment $(64 \%)$ with less than fifty employees. The characteristics of the respondents showed that the majority are males $(62 \%)$, with a diploma/degree $(85 \%)$ and in the $41-50$-year bracket $(56 \%)$.

Table 2. The measurement model (author's data analysis)

\begin{tabular}{|c|c|c|c|c|c|c|}
\hline Construct & $\begin{array}{c}\text { Measurement } \\
\text { items }\end{array}$ & $\begin{array}{l}\text { Mean } \\
\text { and SD }\end{array}$ & $\begin{array}{l}\text { Item } \\
\text { loading }\end{array}$ & $\begin{array}{c}\text { Cronbach's } \\
\text { alpha }\end{array}$ & $\begin{array}{l}\text { Composite } \\
\text { reliability }\end{array}$ & AVE \\
\hline \multirow[t]{4}{*}{$\begin{array}{l}\text { SENSING } \\
\text { (SEN) }\end{array}$} & SEN1 & $\begin{array}{l}4.45 \\
1.06 \\
\end{array}$ & 0.788 & 0.802 & 0.885 & 0.658 \\
\hline & \begin{tabular}{|l|} 
SEN2 \\
\end{tabular} & & 0.764 & & & \\
\hline & SEN3 & & 0.821 & & & \\
\hline & SEN4 & & 0.869 & & & \\
\hline \multirow[t]{5}{*}{$\begin{array}{l}\text { LEARNING } \\
\text { (LEA) }\end{array}$} & LEA1 & $\begin{array}{l}3.96 \\
0.99\end{array}$ & 0.866 & 0.781 & 0.899 & 0.642 \\
\hline & LEA2 & & 0.849 & & & \\
\hline & LEA3 & & 0.788 & & & \\
\hline & LEA4 & & 0.769 & & & \\
\hline & LEA5 & & 0.726 & & & \\
\hline \multirow[t]{5}{*}{$\begin{array}{l}\text { INTEGRATING } \\
(\text { INT) }\end{array}$} & INT1 & $\begin{array}{l}3.06 \\
1.02 \\
\end{array}$ & 0.801 & 0.725 & 0.858 & 0.601 \\
\hline & INT2 & & 0.769 & & & \\
\hline & INT3 & & 0.726 & & & \\
\hline & INT 4 & & 0.804 & & & \\
\hline & INT5 deleted & & 0.388 & & & \\
\hline \multirow[t]{5}{*}{$\begin{array}{l}\text { COORDINATING } \\
\text { (PBC) }\end{array}$} & $\mathrm{COO} 1$ & \begin{tabular}{|l|}
3.48 \\
1.04 \\
\end{tabular} & 0.771 & 0.808 & 0.872 & 0.577 \\
\hline & $\mathrm{COO} 2$ & & 0.729 & & & \\
\hline & $\mathrm{COO} 3$ & & 0.761 & & & \\
\hline & COO4 & & 0.735 & & & \\
\hline & COO5 & & 0.801 & & & \\
\hline \multirow[t]{5}{*}{$\begin{array}{l}\text { PRODUCT } \\
\text { INNOVATION } \\
\text { (PROD) }\end{array}$} & PROD1 & $\begin{array}{l}4.05 \\
1.01\end{array}$ & 0.726 & 0.764 & 0.839 & 0.566 \\
\hline & \begin{tabular}{|l|} 
PROD2 \\
\end{tabular} & & 0.808 & & & \\
\hline & PROD3 & & 0.742 & & & \\
\hline & PROD4 & & 0.731 & & & \\
\hline & PROD5 deleted & & 0.382 & & & \\
\hline \multirow[t]{7}{*}{$\begin{array}{l}\text { PERFORMANCE } \\
\text { (PER) }\end{array}$} & PER1 & $\begin{array}{l}4.08 \\
1.04 \\
\end{array}$ & 0.728 & 0.815 & 0.898 & 0.556 \\
\hline & PER2 & & 0.801 & & & \\
\hline & PER3 & & 0.741 & & & \\
\hline & PER4 & & 0.728 & & & \\
\hline & PER5 & & 0.759 & & & \\
\hline & PER6 & & 0.733 & & & \\
\hline & $\begin{array}{l}\text { PER7 } \\
\end{array}$ & & 0.727 & & & \\
\hline
\end{tabular}

Table 3. Discriminant validity (author's data analysis)

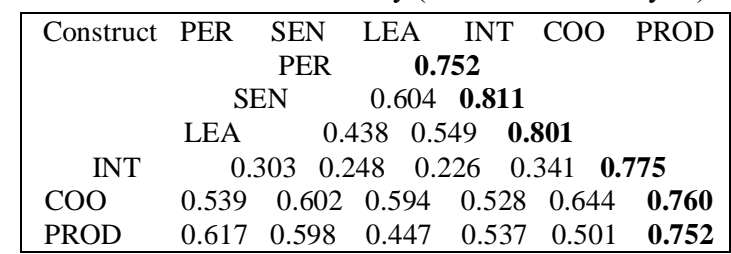

Table 4. Path coefficient and

T-statistics (author's data analysis) $\mathrm{P}<0.01 ; * *<0.05$

\begin{tabular}{|cc|c|c|c|}
\hline \multicolumn{2}{|c|}{ Hypothesised path } & Beta & T-statistics & Decision \\
\hline H1 & SEN $\rightarrow$ PER & 0.161 & $4.200^{*}$ & Accepted \\
\hline H2 & LEA $\rightarrow$ PER & 0.149 & $3.117^{* *}$ & Accepted \\
\hline H3 & INT $\rightarrow$ PER & 0.069 & 1.008 & Rejected \\
\hline H4 & COO $\rightarrow$ PER & 0.152 & $3.005^{*}$ & Accepted \\
\hline H5 & SEN $\rightarrow$ PROD & 0.172 & $1.922^{* *}$ & Accepted \\
\hline H6 & LEA $\rightarrow$ PROD & 0.099 & $1.826^{*}$ & Accepted \\
\hline H7 & INT $\rightarrow$ PROD & 0.048 & 1.114 & Rejected \\
\hline H8 & COO $\rightarrow$ PROD & 0.103 & $1.408^{*}$ & Accepted \\
\hline H9 & PROD $\rightarrow$ PER & 0.149 & $3.001^{*}$ & Accepted \\
\hline
\end{tabular}

Table 5 Mediation results (author's data analysis)

\begin{tabular}{|c|c|c|c|c|c|}
\hline $\begin{array}{l}\text { Mediation } \\
\text { path }\end{array}$ & $\begin{array}{l}\text { Indirect } \\
\text { effect }\end{array}$ & $\begin{array}{c}\text { Total } \\
\text { effect and } \\
\text { T-statistics }\end{array}$ & $\begin{array}{c}\text { Confidence } \\
\text { interval bias } \\
\text { (corrected) }\end{array}$ & Decision & VAF \\
\hline & & & LL UL & & \\
\hline $\begin{array}{c}\mathrm{H} 10 \\
\mathrm{SEN} \rightarrow \mathrm{PR} \\
\mathrm{OD} \rightarrow \mathrm{PER}\end{array}$ & $0.088^{* * *}$ & $\begin{array}{c}0.282 * * \\
(3.771)\end{array}$ & $\begin{array}{l}0.514 \\
0.228\end{array}$ & $\begin{array}{c}\text { Accepted } \\
\text { (partial) }\end{array}$ & $\begin{array}{c}31.20 \\
\%\end{array}$ \\
\hline $\begin{array}{c}\mathrm{H} 11 \\
\mathrm{LEA} \rightarrow \mathrm{PR} \\
\mathrm{OD} \rightarrow \mathrm{PER}\end{array}$ & $0.116^{* *}$ & $\begin{array}{c}0.291 * * \\
(3.005)\end{array}$ & $\begin{array}{l}0.068 \\
0.314\end{array}$ & $\begin{array}{c}\text { Accepted } \\
\text { (partial) }\end{array}$ & $\begin{array}{c}39.86 \\
\%\end{array}$ \\
\hline $\begin{array}{c}\mathrm{H} 12 \\
\mathrm{INT} \rightarrow \mathrm{PR} \\
\mathrm{OD} \rightarrow \mathrm{PER}\end{array}$ & 0.099 & $\begin{array}{c}1.355 \\
(1.006)\end{array}$ & $\begin{array}{l}0.071 \\
0.301\end{array}$ & \begin{tabular}{|c} 
Rejected \\
(no \\
mediation)
\end{tabular} & $\begin{array}{c}6.64 \\
\%\end{array}$ \\
\hline $\begin{array}{c}\mathrm{H} 13 \\
\mathrm{COO} \rightarrow \mathrm{PR} \\
\mathrm{OD} \rightarrow \mathrm{PER}\end{array}$ & 0.092 & $\begin{array}{c}1.022 \\
(1.125)\end{array}$ & $\begin{array}{l}0.066 \\
0.188\end{array}$ & $\begin{array}{l}\text { Rejected } \\
\text { (no } \\
\text { mediation) }\end{array}$ & $\begin{array}{c}9.00 \\
\%\end{array}$ \\
\hline
\end{tabular}

\section{Structural equation modelling}

\subsection{Measurement model}

Hair et al. (2019) point out that the evaluation of the measurement model should include the examination of factor loadings $(>0.708)$, composite reliability $(>0.790)$, Cronbach's alpha $(>0.700)$ and the AVE $(>0.500)$. Table 2 presents the results of the measurement model. The values of the Cronbach's alphas are greater than 0.700 , the values of composite reliability range from 0.839 to 0.900 and the values of AVE from 0.566 to 0.658 . This implies an acceptable level of construct validity. The AVEs ranged between 0.566 and 0.658 suggesting a good convergent validity of the scales. The discriminant validity was assessed 
through the Fornell and Larcker criteria. The results as depicted by table 3 showed that the square roots of AVEs depicted on the diagonals are greater than the corresponding correlation coefficients within the constructs. It can be concluded that the measurement model is satisfactory. Diagonals in bold signify the square root of the AVE while the other figures depict the correlations.

\subsection{Structural model}

To assess the structural model, the common method bias, the goodness of fit, the $\mathrm{R}^{2 \text {, the }} \mathrm{Q}^{2}$ and the effect size were evaluated in line with the requirements of Hair et al. (2019). The summary of the results of the path coefficients and T-statistics are presented in tables 4 and 5. The results as depicted in table 4 show that three dimensions of dynamic capabilities (sensing, learning and coordinating) have direct and significantly positive relationships with performance. The effect of integration is positive but insignificant. Therefore, hypotheses one, two and four are accepted while hypothesis three is rejected. The relationships between sensing, learning and coordinating and innovation are significant and hypotheses five, six and eight are accepted. The relationship between product innovation and performance is significant and hypothesis nine is accepted. The two phases of mediation were examined. (1) the determination of the significance and magnitude of the indirect effects (done through a bootstrap of 5000 subsamples and confidence interval to obtain information about the population distribution) and (2) the determination of the type of effect and or mediation which can be full or partial and competitive or complementary. The existence of full or partial mediation can be determined by the Variance Accounted For (VAR). If the VAR is less than 20\%, mediation is close to zero, for VAR value between 20\% and 80\% (partial mediation and above 80\% (full mediation) (Nitzl et al., 2016; Hair et al., 2019). Table 5 depicts the summary results of mediation. The indirect paths between sensing and learning and product innovation and performance are positive and significant. Thus a complementary partial mediation partial is confirmed. Hypotheses ten and eleven are accepted. The indirect paths between integrating and performance are insignificant. Hypotheses twelve and thirteen are rejected.

\section{DISCUSSION}

The study investigated the effect of four dimensions of DC on performance of hospitality firms. In addition, the study examined if product innovation mediates the relationship between DC and performance. This is because innovation is a vital to a firm's competitive advantage and superior performance. Although DC is an important framework for understanding firm competitive advantage, empirical research focusing on the hospitality industry is scarce. The results indicated that sensing, learning and coordinating capabilities significantly affect the performance of hospitality firms. The effect of integrating capability is insignificant. According to Nieves et al. (2017) and Rashidirad and Salimian (2020), sensing capability focuses on the search for opportunities and threats in order to shape and interpret opportunities in the market. The identification of new opportunities can increase sales and market share with a positive impact on performance. Learning capability is an asset that enables a firm to transform and use its resources appropriately and the appropriate use of resources can positively affect performance (Zott, 2003). Coordinating capability helps a firm to manage a rapidly changing business environment maintain customers and improve performance through a dynamic redirecting and realigning the resource base (Pavlou and El-Sawy, 2011; Rashidirad and Salimian, 2020). The findings of the study are consistent with previous empirical studies on DC and firm performance. Kimani and Otinga (2019) in a study done on manufacturing firms in Kenya find that DC significantly affect performance. The findings of the study by Pervan et al. (2017) based on a sample of 118 small manufacturing firms in Croatia reveal a statistically significant impact of DC on performance. Garrido et al. (2019) in a study that adopted Teece's conceptual dimensions (sense, seizing and reconfiguring) find that the three factors affect performance differently. While sensing and reconfiguration demonstrate a negative relationship with performance, the effect of seizing is positively associated with performance. Nedzinskas et al. (2013) investigate the effect of DC on the performance of SMEs in Lithuania.

The study based on a sample of 360 SMEs used both financial and non-financial measures to measure performance. The findings indicate that DC as measured by sensing, seizing and reconfiguration have positive effects on non-financial performance but their effects on financial performance are insignificant. Empirical studies have also examined the mediating effects of some variables in the relationship between DC and performance. Pattanasing et al., (2019) find that DC positively affect the performance of organisations. The findings of the study show that the indirect effect of DC on performance via the high-performance firm is significant Hernández-Linares et al. (2018) in a sample of 500 small and medium enterprises in Spain find that not all the four dimensions of DC are equally important for performance. In addition, the study finds the moderation effect of market orientation in the relationship between sensing and learning capabilities and performance. Zhou et al. (2017) in a sample of 204 Chinese firms find direct significant relationships between sensing and reconfiguration capabilities and firm performance. The direct relationship between integration and performance is not significant. In addition, technological innovation mediates the relationship between sensing and reconfiguration capabilities and firm performance. Market innovation also mediates the relationship reconfiguration capability and firm performance. The mediation effects of technological and market innovation in the relationship between other DC dimensions and performance are not significant.

\section{CONCLUSION}

The study investigated the effect of DC on the performance of hospitality firms in South Africa. In addition, the studies examined the mediating effect of product innovation in the relationship between DC and performance. The results indicated that three dimensions of DC (sensing, learning and coordinating) have significant positive relationships with performance. Product innovation mediates the relationship between sensing and learning capabilities and performance. The study has some theoretical contributions. First, the study conceptualised DC as a multidimensional construct made up of four variables rrather than treating the construct as unidimensional. Thus, the study was able to determine the effect of each DC variable on performance. In addition, the study examined the mediating effect of innovation in the relationship between DC and performance. Theoretically, the study established that the relationship between DC and performance can be direct and indirect 
through the mediating effect of product innovation. In addition, while studies have tended to focus on the effect of DC on financial performance, the performance indicators used in this study included both financial and non-financial metrics. Empirically, the study adds to the body of literature on the relationship between DC dimensions, innovation and performance of hospitality firms. The study has some managerial implications. The findings show that three variables affect performance and the indirect effect of innovation. Therefore, it is important for top managers of hospitality firms to invest in DC to sustain competitive advantage. The findings also show that DC will be more useful when hospitality firms invest in product innovation. Thus, the provision of seminars and training on DC and innovation to top management and employees is important. Top management must foster an environment that supports the generation of new ideas by employees and the coordination of such ideas to improve products and services. The study has some limitations and proposes some areas for further study.

The survey was cross-sectional in nature and data was collected at only one point in time. Therefore, other studies can employ a longitudinal study design to better confirm causality. In addition, the mediating effects of environmental dynamism, market orientation and entrepreneurial orientation can be examined by other studies. In addition, the study focused on the indirect effect of product innovation. Other studies can investigate the mediating effect of other types of innovation (process, organisational and marketing). Furthermore, the moderating effect of age and size of the firm can be examined.

\section{REFERENCES}

Alshanty, A.M., \& Emeagwali, O.L. (2019). Market-sensing capability, knowledge creation and innovation: The moderating role of entrepreneurial-orientation. Journal of Innovation \& Knowledge, 4 (3), 171-178. https://doi.org/10.1016/j.jik.2019.02.002

Altintas, G., \& Ambosini, V. (2019). Dynamic Managerial capabilities. Business Policy and Strategy, 1, 2-18. https://doi.org/10.1093/acrefore/9780190224851.013.20

Aminu, M. (2015). Mediating Role of Dynamic Capabilities on the Relationship between Intellectual Capital and Performance: A Hierarchical Component Model Perspective in PLS-SEM Path Modelling. Research Journal of Business Management, 9(3), 443-456. https://doi.org/10.3923/rjbm.2015.443.456

Amit, R., \& Schoemaker, P. (1993). Strategic Assets and Organizational Rent. Strategic Management Journal, 14(1), 33-46. https://doi.org/10.1002/smj.4250140105

Andrews, K. (1971). The Concept of Corporate Strategy. Irwin: Homewood.

Backman, M., Klaesson, J., \& Oner, O. (2017). Innovation in the hospitality industry: Firm or location? Tourism Economics, 23(8), 15911614. https://doi.org/10.1177/1354816617715159

Baregheh, A., Rowley. J., \& Sambrook, S. (2009). Towards a multidisciplinary definition of innovation. Management Decision, 47(8), 13231339. https://doi.org/10.1108/00251740910984578

Barney, J. (1991). Firm Resources and Sustained Competitive Advantage. Journal of Management, 17 (1), 99-120. https://doi.org/10.1177/014920639101700108

Barreto, I. (2010). Dynamic Capabilities: A Review of Past Research and an Agenda for the Future. 36(1), 256-280. https://doi.org/10.1177/0149206309350776

Božič, V., \& Cvelbar, L. (2016). Resources and capabilities driving performance in the hotel industry. Tourism and Hospitality Management, 22(2), 225-246. https://doi.org/10.20867/thm.22.2.8

Chipunza, L.T. (2020). Innovation in small accommodation businesses: A comparative study of Zimbabwe and South Africa. Acta Commercii, 20(1), a796. https://doi.org/10.4102/ac.v20i1.796

Colombo, M., Piva, E., Quas, A., \& Lamastra, C. (2010). Dynamic Capabilities During the Global Crisis: Evidence from Italian New Technology Based Firms. SSRN 1722507. https://doi.org/10.2139/ssrn.1722507

Duchek, S. (2020). Organizational resilience: a capability-based conceptualization. Business Research 13, $215-246$. https://doi.org/10.1007/s40685-019-0085-7

Eisenhardt, K.M., \& Martin, J.A. (2000). Dynamic capabilities: what are they? Strategic Management Journal, 21, 1105-1121. https://doi.org/10.1002/1097-0266

Ferreira, J.C., \& Coelho, L. (2020). Dynamic capabilities, creativity and innovation capability and their impact on competitive advantage and firm performance: The moderating role of entrepreneurial orientation. Technovation, 92, 1-18. https://doi.org/10.1016/j.technovation.2018.11.004

Garrido, I., Kretschmer, C., Vasconcellos, S., \& Gonçalo, C. (2019). Dynamic Capabilities: A Measurement Proposal and its Relationship with Performance. Brazilian Business Review. 17(1), 46-65. https://doi.org/10.15728/bbr.2020.17.1.3

Gorochnaya, V., Mikhaylov, A., Plotnikova, A., \& Mikhaylova, A. (2021). The interdependence between tourism and innovation activity in the western borderlands of Russia. GeoJournal of Tourism and Geosites, 34(1), 147-154. https://doi.org/10.30892/gtg.34119-630

Hair, J.F., Risher, J.J., Sarstedt, M., \& Ringle, C.M. (2019). When to Use and How to Report the Results of PLS-SEM. European Business Review, 31(1), 2-24. https://doi.org/10.1108/EBR-11-2018-0203

He, Z.L., \& Wong, P.K. (2004). Exploration versus exploitation: An empirical test of the ambidexterity hypothesis. Organization Science, 15(4), 481-494. https://doi.org/10.1287/orsc.1040.0078

Helfat, C.E., Finkelstein, S., Mitchell, W., Peteraf, M., Singh, H., Teece, D.J., \& Winter, S. (2007). Dynamic Capabilities: Understanding Strategic Change in Organizations. Malden M.A: Blackwell.

Helfat, C., \& Winter, S. (2011). Untangling Dynamic and Operational Capabilities: Strategy for the (N)ever-Changing World. Strategic Management Journal. 37(11), 1243-1250. https://doi.org/10.1002/smj.955

Hernández-Linares, R., Kellermanns, F., \& López-Fernández, M. (2018). Dynamic Capabilities and SME Performance: The Moderating Effect of Market Orientation. Journal of Small Business Management, 59(11), 162-195. https://doi.org/10.1111/jsbm.12474

Jensen, M.B., Johnson, B.H., Lorenz, E., \& Lundvall, B.A. (2007). Forms of Knowledge and Modes of Innovation. Research Policy, 36(5), 680-693. https://doi.org/10.1016/j.respol.2007.01.006

Jiang, W., Mavondo, F., \& Zhao, W. (2019). The impact of business networks on dynamic capabilities and product innovation: The moderating role of strategic orientation. Asian Pacific Journal of Management. 37, 1239-1266. https://doi.org/10.1007/s10490-018-9628-2

Jiménez-Jiménez, D., \& Sanz-Valle, R. (2011). Innovation, organizational learning, and performance. Journal of Business Research, 64(4), 408-417. https://doi.org/10.1016/j.jbusres.2010.09.010

Kimani, M., \& Otinga, H. (2019). Influence of dynamic capabilities on firm performance in the manufacturing sector in Kenya. a case of Ketepa limited. Strategic Journal of Business \& Change Management, 6(1), 719-732.

Kogabayev, T., \& Maziliauskas, A. (2017). The definition and classification of innovation. HOLISTICA - Journal of Business and Public Administration, 8(1), 61-72. https://doi.org/10.1515/hjbpa-2017-0005 
Likoum, S.W.B., Shamout, M.D., Harazneh, I., \& Abubakar, A.M. (2018). Market-sensing capability, innovativeness, brand management systems, market dynamism, competitive intensity, and performance: An integrative review. Journal of the Knowledge Economy, 11 (2), 593-613. https://doi.org/10.1007/s13132-018-0561-x

Makadok, R. (2001). Toward a Synthesis of the Resource-Based and Dynamic-Capability Views of Rent Creation. Srategic Management Journal, 22 (5), 387-401. https://www.jstor.org/stable/3094265

Mabrouk, A., \& Mamoghli, C. (2010). Is Financial Innovation Influenced by Financial Liberalization? Evidence from the Tunisian Banking Industry. Banks and Bank Systems, 5(3), 97-111.

Martin-Rios, C., \& Ciobanu, T. (2018). Hospitality Innovation strategies: An analysis of success factors and challenges. Tourism Management, 70, 218-229. https://doi.org/10.1016/j.tourman.2018.08.018

Matysiak, L., Rugman, A., \& Bausch, A. (2018). Dynamic Capabilities of Multinational Enterprises: The Dominant Logics Behind Sensing, Seizing, and Transforming Matter. Management International Review. 58(2). 225-250. https://doi.org/10.1007/s11575-017-0337-8

Mesa, A.F., Méndez, J.L., Vidal, J.A., \& Chiva, R. (2013). IT competency and the commercial success of innovation. Industrial Management \& Data Systems, 114(4), 550-567. https://doi.org/10.1108/IMDS-09-2013-0389

Migdadi, M. (2019). Organizational learning capability, innovation and organizational performance. European Journal of Innovation Management, 24(1), 151-172. https://doi.org/10.1108/EJIM-11-2018-0246

Nedzinskas, S., Pundziene, A., Rafanaviciene, S., \& Pilkiene, M. (2013). The impact of dynamic capabilities on SME performance in a volatile environment as moderated by organizational inertia. Baltic Journal of Management, 8(4), 376-396. https://doi.org/10.1108/BJM-01-2013-0003

Nieves, J., \& Haller, S. (2014). Building dynamic capabilities through knowledge resources. Tourism Management, 40, $224-232$. https://doi.org/10.1016/j.tourman.2013.06.010

Nieves, J., Quintana, A., \& Osorio, J. (2016). Organizational knowledge, dynamic capabilities and innovation in the hotel industry. Tourism and Hospitality Research, 16(2), 158-171. https://doi.org/10.1177/1467358415600208

Nhepera, N., \& Onojaefe, D. (2019). An Examination of the Importance of Hotel Innovation on Guest Loyalty in Cape Town, South Africa. Acta Universitatis Danubius, (Economica), 15(2), 70-81. http://www.journals.univ-danubius.ro/index.php/oeconomica/article/view/5225

Nitzl, C., Roldan, J.L., \& Cepeda-Carrion, G. (2016). Mediation Analysis in Partial Least Squares Path Modelling: Helping Researchers Discuss More Sophisticated Models. Industrial Management \& Data Systems, 116(9), 1849-1864. https://doi.org/10.1108/IMDS-07-2015-0302

Ntshangase, S.D., \& Ezeuduji, I.O. (2020). Profiling entrepreneurial behaviour based on demographic variables: tourism-related entrepreneurs in Mtubatuba Local Municipality, South Africa. GeoJournal of Tourism and Geosites, 31(3), 944-950. https://doi.org/10.30892/gtg.31302-525

Oliva, F., Couto, M., Santos, R., \& Bresciani, S. (2019). The integration between knowledge management and dynamic capabilities in agile organizations. Management Decision, 57(5). https://doi.org/10.1108/MD-06-2018-0670

Pasara, M., \& Garidzirai, R, (2020). Causality effects among gross capital formation, unemployment and economic growth in South Africa. Economies, 8(26), 1-12. https://doi.org/10.3390/economies8020026

Pattanasing, K., Aujirapongpan, S., \& Srimai, S. (2019). Dynamic capabilities and high performance organization of hotel business: empirical investigation into world class tourism destination. Tourism and Hospitality Management, 25(2), 377-401. https://doi.org/10.20867/thm.25.2.8

Pavlou, P.A., \& El Sawy, O.A. (2011). Understanding the Elusive Black Box of Dynamic Capabilities. Decision Sciences, 42(1), $239-273$. https://doi.org/10.1111/j.1540-5915.2010.00287.x

Penrose, E. T. (1959). The Theory of the Growth of the Firm. New York: John Wiley.

Pervan, M., Curak, M., \& Kramaric, T. (2017). The Influence of Industry Characteristics and Dynamic Capabilities on Firms' Profitability. International Journal of Financial Studies, 6(1), 1-19. https://doi.org/10.3390/ijfs6010004

Peteraf, M.A., Di Stefano, G., \& Verona, G. (2014). The Organizational Drivetrain: A Road To Integration Of Dynamic Capabilities Research. Academy of Management Perspectives, 28(4), 1-33. https://doi.org/10.5465/amp.2013.0100

Rajapathirana, R.P., \& Hui, Y. (2018). Relationship between innovation capability, innovation type, and firm performance. Journal of Innovation \& Knowledge, 3(1)1-15. https://doi.org/10.1016/j.jik.2017.06.002

Rashidirad, M., \& Salimian, H., (2020). SMEs' dynamic capabilities and value creation: the mediating role of competitive strategy. European Business Review, 32(4): 591-613. https://doi.org/10.1108/EBR-06-2019-0113

Rehman, K., \& Saeed, Z. (2015). Impact of Dynamic Capabilities on Firm Performance: Moderating Role of Organizational Competencies.

Sukkur Journal of Management Business 2(2), 18-40. https://doi.org/10.30537/sijmb.v2i2.92

Richard, B. (2017). Hotel chains: Survival strategies for a dynamic future. Journal of Tourism Futures, 3(1), 56-65. https://doi.org/10.1108/JTF-06-2016-0018

Rengkung, LR (2018). Modelling of dynamic capabilities: a system dynamics approach. Academy of Strategic Management Journal, $17(5), 1-14$.

Senbeto, D.L., \& Hon, H.Y. (2020). Market turbulence and service innovation in hospitality: examining the underlying mechanisms of employee and organizational resilience. The Service Industries Journal, 40, 15-16. https://doi.org/10.1080/02642069.2020.1734573

Seo, K., Woo, L., Mun, S., \& Soh, J. (2021). The asset-light business model and firm performance in complex and dynamic environments: The dynamic capabilities view. Tourism Management, 85, 1-11. https://doi.org/10.1016/j.tourman.2021.104311

Skokic, V., Lynch, P., \& Morrison, A. (2016). Hotel entrepreneurship in a turbulent environment. International Journal of Hospitality Management, 53, 1-11. https://doi.org/10.1016/j.ijhm.2015.11.008

Teece, D.J., Pisano, G., \& Shuen, A. (1997). Dynamic Capabilities and Strategic Management. Strategic Management Journal. 18 (7), 509 533. https://doi.org/10.1002/(sici)1097

Teece, D.J. (2007). Explicating dynamic capabilities: The nature and microfoundations of (sustainable) enterprise performance. Strategic Management Journal, 28(13), 1319-1350. https://doi.org/10.1002/smi.640

Winter, S.G. (2003). Understanding dynamic capabilities. Strategic Management Journal. 24(10), 991-995. https://doi.org/10.1002/smj.318

Zahra, S., Sapienza, H., \& Davidsson, P. (2006). Entrepreneurship and Dynamic Capabilities: A Review, Model and Research Agenda. Journal of Management Studies, 43(4), 917-955. https://doi.org/10.1111/j.1467-6486.2006.00616.x

Zhou, S., Zhou, A., Feng, J., \& Jiang, S. (2017). Dynamic capabilities and organizational performance: The mediating role of innovation. Journal of Management \& Organization, 25(5), 731-774. https://doi.org/10.1017/jmo.2017.20

Zollo, M., \& Winter, S. (2002). Deliberate Learning and the Evolution of Dynamic Capabilities. Organization Science, 13(3), 339-339. https://doi.org/10.1287/orsc.13.3.339.2780

Zott, C. (2003). Dynamic capabilities and the emergence of intraindustry differential firm performance: insights from a simulation study. Strategic Management Journal, 24, 97-125. https://doi.org/10.1002/smj.288

*** World Travel and Tourism Council (2019). Economic impact report. Accessed 05.02.2021. https://wttc.org/Research/Economic-Impact 